\title{
Conceptualising External and Internal Quality Assurance in Higher Education: A Pragmatist Perspective
}

\author{
Francis Ansah
}

\begin{abstract}
The traditional tension between external and internal quality assurance implementation in higher education appears to be declining, based on a rethinking of the relationship between the two concepts. Although there are quality assurance agencies that still consider external and internal quality assurance as separate entities, most quality assurance agencies now regard the two concepts as complementary. In this paper, a case is put that the present rethinking of external and internal quality assurance in most higher education settings is guided by pragmatism, but not explicitly acknowledged in the literature. For a better appreciation of pragmatists' influence on the current understanding of the relationship between external and internal quality assurance in higher education, this paper provides a further pragmatist conceptualisation of the two concepts to enhance stakeholders' appreciation of employing a pragmatist approach to quality assurance practices in higher education. The conceptualisation is done through a pragmatist analysis of selected international accounts on higher education quality assurance. The paper concludes that pragmatism helps to understand external and internal quality assurance as nested concepts with reciprocities of accountability and improvement roles, and influences which call for alignment of perspectives through negotiations and settlements in order to focus on their practical relevance for implementation in higher education.
\end{abstract}

La tension traditionnelle entre l'implémentation de systèmes d'assurance qualité interne et externe dans l'enseignement supérieur semble s'affaiblir grâce à la reconsidération de la relation entre ces deux concepts. Bien qu'il existe des agences d'assurance qualité qui continuent à considérer les assurances qualité interne et externe comme deux entités distinctes, la plupart des agences considèrent désormais qu'elles 
sont complémentaires. Cet article soutient que la nouvelle manière de penser les assurances qualité interne et externe dans l'enseignement supérieur est guidée par un souci de pragmatisme mais est encore peu reconnue dans la littérature. Pour mieux apprécier l'influence des pragmatistes sur la compréhension actuelle de la relation entre les assurances qualité interne et externe, cet article offre une conceptualisation pragmatique approfondie de ces deux concepts dans le but d'augmenter l'appréciation des parties prenantes pour l'utilisation d'une telle approche. La conceptualisation proposée provient d'une analyse pragmatique d'un choix d'expériences internationales en matière d'assurance qualité pour l'enseignement supérieur. En conclusion, cet article affirme que le pragmatisme aide à comprendre les assurances qualité interne et externe comme des concepts imbriqués qui ont des rôles réciproques en ce qui concerne la responsabilisation du système et son amélioration. Ces rôles ainsi que l'influence exercée par ces deux types d'assurance qualité requièrent des négociations et accords, pour s'accorder sur les perspectives et pouvoir ensuite se concentrer pleinement sur la pertinence pratique de leur implémentation dans les systèmes d'enseignement supérieur.

\section{Introduction}

The centrality of higher education to societal development has led to increasing global attention to the issue of quality in contemporary higher education (OECD, 2006). Contemporary higher education systems and institutions are constantly under pressure to meet stakeholders' expectations of quality (OECD, 2006). Over the last two decades, stakeholders' concerns about contemporary higher education quality have intensified (Bernhard, 20I2; Harvey \& Williams, 20Iо). The concerns have been linked to several factors including: mass participation and diversification; marketisation and privatisation; the changing role of the state and the decline of state funding; globalisation and internationalisation; and the development of new technologies (Bigalke, 2009; Bigalke \& Neubauer, 2009; Santiago, Tremblay, Basri, \& Arnal, 2008).

According to Harman and Meek (2000), in the past, universities and government agencies employed terms such as academic standards, standards of degrees, student assessment and accountability to represent the quality of higher education. Green (I994) claims that until the mid-I980 any debate about quality in higher education was internal to the higher education sector. She adds that when the quality debate became a public issue, the response of academics was bewilderment and a sense of injustice. She argues further that this is because the assumption was that academic standards were safe in the hands of the universities, and because of indignation that the integrity of the academic profession should be impugned by the demand for public accountability.

The situation demands a societal debate, given the role of higher education in societal development (Bigalke \& Neubauer, 2009; Blackmur, 2007; Dill, 2007). This is why the global fascination with quality assurance in contemporary higher education can be considered legitimate, because it is intended to address societal expectations of quality (Singh, 20Io; Srikanthan \& Dalrymple, 2003).

According Harvey and Williams (20I0), some authors consider quality assurance to be a strategy that can enhance the quality of higher education, while others have questioned the link between quality assurance and quality education. The call to address social expectations beyond what is internal to higher education institutions, has resulted in a differentiation between external and internal quality assurance. Some authors (Skolnik, 20I0; Vroeijenstijn, I995) have alluded to tensions between external and internal quality assurance implementation in higher education. This tension, purported to have negative effects on the implementation of the two concepts in higher education, has been predicated on the clash of expectations between external and internal stakeholders of higher education (Leisyte \& Westerheijden, 20I4). External stakeholders' demands on higher education institutions are sometimes interpreted as promoting obsession with formal structures that burden academic staff with excessive paper work (Cheng, 2009). Internal stakeholders' demand for professional autonomy is interpreted as promoting their exclusive right to determine quality (Srikanthan \& Dalrymple, 2003). These interpretations of the two concepts make them appear mutually exclusive. External quality assurance is described as promoting accountability, while internal quality assurance is described as promoting improvement.. This results in tensions that affect their implementation negatively.

However, the interpretations of the two concepts appear to be changing in most higher education settings. The Tuning Project, which has had a major influence on the quality assurance landscape in higher education in most continents, at least on the quality of study programmes, has emphasised that quality at programme level is the primary responsibility of higher education institutions. Quality assurance agencies are there to complement the efforts of higher education institutions (Tuning Educational Structures in Europe Project, 20I2; Lokhoff et al., 20I0). These complementary roles guide the activities of many quality assurance agencies in higher education. 
The aim of this paper is to make an argument that the present rethinking of the relationship between external and internal quality assurance is guided by a pragmatist orientation, although not explicitly acknowledged in the literature. The paper then provides a pragmatist's conceptualisation of external and internal quality assurance, to further enhance stakeholders' understanding of the interrelationships and the roles of external and internal quality assurance in higher education, and to minimise any perceived tension when implementing the two concepts in higher education settings where the concepts are still considered separate entities.

Before a pragmatist approach is used to analyse the conceptualisation of external and internal quality assurance in higher education, it is important to consider other approaches that have influenced the operationalisation of quality assurance in higher education.

\section{Quality Assurance in Higher Education}

The debates around quality as a concept in higher education have been extended to quality assurance. Different perspectives have been used to conceptualise quality in higher education. Sebastianelli and Tamimi (2002) have shown that different conceptualisations of quality have resulted from five major approaches to defining quality: transcendent, product-based, manufacturing-based, value-based and user-based. The authors believe that these five approaches capture all the academic and professional discourses about quality in the literature.

Just as with the concept of quality, there has not been a single universally accepted construct quality assurance in higher education; the same applies to practice. There even appears to be much confusion about the terms used to operationalise quality assurance in higher education (Lewis, 2009; Frazer, I994;). Terminologies such as quality control, quality assurance, quality management, quality audit, accreditation, validation, peer review, quality assessment and quality measurement are used in relation to the operationalisation of quality assurance in higher education (Bernhard, 2012; Mishra, 2007; Frazer, 1994). These terminologies have different meanings in different educational cultures, and some are also used interchangeably. For example, in the United States the system of assuring and improving quality in higher education is called accreditation (Schwarz \& Westerheijden, 2007), whereas in Australia, the national system of assuring and improving quality in universities is termed quality audit (Santiago et al., 2008). In Ghana, the national system of operationalising quality assurance in higher education is called accreditation (Ansah, 2010). "Accreditation in Australia refers to the initial registration of an institution through government legislation" (Vidovich, 2002, p. 8) and it is seen as different from quality assurance. In Ghana, accreditation is considered in terms of both initial registration of an institution and its programmes, and monitoring device (Oyewole, 20I2). The multiple meanings of terms used to operationalise quality within and across countries make it difficult to have universally accepted construct and practice of quality assurance in higher education. Alabi (2008 cited in Oyewole, 20I2) refers to quality assurance as monitoring the activities of higher education.

The different approaches to conceptualising quality and quality assurance in higher education have resulted in external and internal quality assurance traditionally regarded as regulatory and developmental respectively (Skolnik, 20I0; Sanyal \& Martin, 2007). The transcendental approaches to quality make external quality assurance regulatory, because quality is regarded as an ideal which cannot be compromised (Sallis and Kingly cited in Harvey \& Green, I993). On the other hand, the non-transcendental approaches consider quality as a negotiable phenomenon by different stakeholders (Srikanthan \& Dalrymple, 2003).

The different perspectives have led to a contemporary rethinking of the relationship between external and internal quality assurance in higher education settings, where the regulatory view of external quality assurance is appropriately balanced with developmental perspectives, because there is a need for a model that entails reciprocal roles and safeguards (Poole, 20I0; Finnish Higher Education Evaluation Council, 2008). This rethinking of the relationship between external and internal quality assurance is argued in this paper as a pragmatist approach, although this is not explicitly acknowledged.

\section{A Pragmatist Approach}

As a worldview, pragmatism rejects an a priori judgement system or solipsist view of a phenomenon, and argues for different perspectives to be aligned to solve a practical problem, because knowledge is transactional (Biesta, 20Io). Also, from a pragmatist view, knowledge about concepts is not eternal, but subject to changes. Quality assurance in higher education, whether external or internal, is a dynamic concept subject to the changing trends of higher education. There are also multiple realities of quality assurance in higher education, because of the differences in perspectives of stakeholders such as funding bodies, employers of graduates, employees of higher education institutions, and students. All these stakeholders look at quality assurance from different angles (Srikanthan \& Dalrymple, 2003). This challenges any a priori judgement system or solipsist view of quality assurance in higher education. 
Pragmatists believe in multiple realities, and argue that consensus achieved through debate, settlements and alignment of different perspectives is required to solve practical problems (Schwartz, 20I2; Biesta 20I0; Greene \& Hall, 20I0). From a pragmatist view, both external and internal quality assurance mechanisms should go through a process of negotiations and settlements by stakeholders, in order to align different perspectives to address a common practical problem of improving higher education outcomes.

Additionally, some pragmatists (Symbolic Interactionists) consider pragmatism as a theory of meaning based on perspectives, and emphasise that the meaning of a concept must be clear to everyone involved in its implementation (Bacon, 20I2). For example, whatever gets enacted in the name of quality assurance represents the implementers' meaning of quality. This is why the alignment of stakeholders' perspectives of quality assurance in higher education is essential for enacting quality.

The key attributes of pragmatism, which this paper draws upon, are:

I. Multiple realities of concepts such as quality and quality assurance;

2. The need to provide logical proof(s) of claims;

3. The need to engage in negotiations and settlements, because knowledge is transactional;

4. The imperative of context;

5. Shared responsibilities;

6. Continuous alignment because knowledge is subject to change.

Given that the phenomena of quality and quality assurance in higher education have over the years been considered with these key attributes of pragmatism, it is important to analyse their conceptualisation and implementation from a pragmatist perspective.

Before a pragmatist conceptualisation of external and internal quality assurance in higher education can be provided below, it is imperative to demonstrate an understanding of a pragmatist perspective of 'quality' in higher education in order to put the conceptualisation in context.

\section{A Pragmatist View of Quality in Higher Education}

From a pragmatist standpoint, it is argued that no single construct of quality can fit all sectors and situations due to contextual factors and the perspectives of different stakeholders. The success of any particular construct of quality can be determined if we decide on its purpose, and whom it is meant to satisfy. Given that a purpose can have multiple perspectives, a pragmatist interpretation of fitness for purpose means that there is a continuous alignment of different perspectives of a particular purpose, in order to ensure that that purpose is a negotiated one. Besides, there is also a possibility of shifting emphases of purpose, as judged by practical effects on stakeholders. For example, fitness for purpose in higher education has several stakeholder perspectives: funders (government and the larger community); users of the products/programmes (current and prospective students); users of outputs (employers of graduates); employees of the institutions (academics and administrators); and local and international stakeholders (Srikanthan \& Dalrymple, 2003). Even though their perspectives may not have equal weight, it is important to negotiate for a settlement acceptable to all the perspectives because all stakeholders are important, so that fitness for purpose becomes fitness for purposes. This suggests that a pragmatist construct of fitness for purpose of quality is what is required, in order to meet the diverse needs of higher education stakeholders. A pragmatist view rejects the use of an a priori judgement system or solipsist view for defining quality in higher education; quality definitions should be based on negotiations, settlements and alignment of relevant stakeholder perspectives in order to enhance stakeholder support for enactment. All relevant stakeholders have contributions to make towards enactment of quality in higher education. For example, students as stakeholders have their special contributions to make through feedback on courses and membership on governance committees (Leisyte \& Westerheijden, 20I4). Even though negotiations, settlements and alignments of different stakeholder perspectives are a challenging task, they are worth the effort if the process produces a meaning of quality common for diverse stakeholders.

\section{A Pragmatist View of Quality Assurance in Higher Education}

Quality assurance as a domain of policy in higher education can be traced back to over a century, to the first accreditation organisation in the United States (Ewell, 2007). Quality assurance was an issue of limited interest because higher education then consisted of small, socially homogeneous institutions that did not demand more formal management. Ewell argues that "there is no need to look to further causes than the size of higher education systems today to realize that quality assurance is here to stay" (ibid p. 2).

The current dynamics in contemporary higher education have also raised the profile of quality assurance (Milliken \& Colohan, 2004). As Harvey and Knight (I996) argue, quality can no longer be taken for granted in higher education. The environment of contemporary higher education requires that mechanisms are put in place to protect stakeholders of higher education, including the higher institutions themselves (Sanyal \& Martin, 2007). Stensaker (2007) argues that quality assurance is not just the latest fad but a remarkably success- 
ful management tool, and Harvey and Newton (2007) add that it is sustained by government endorsement because it provides a means of securing accountability. Harvey and Knight (cited in Harvey \& Newton I996, p. I) have indicated how "quality assurance underpins processes of delegated authority in systems in diverse market arrangements in the United States, autonomous public systems in the United Kingdom, the previously ministerial-controlled systems in Scandinavia and tightly constrained systems such as China". This suggests that quality assurance has been useful for diverse systems of higher education globally.

The multiplicity of terminologies in relation to quality assurance, coupled with different interpretations of the same terminologies, highlights the advantages of a pragmatist view of quality assurance in higher education. From a pragmatist perspective, quality assurance refers to negotiated and settled mechanisms used to guarantee and enact the meaning of quality in higher education. These mechanisms are usually sets of external and internal protocols or principles used to guarantee and enact the meaning of quality in higher education (Mishra, 2007). The external and internal mechanisms are necessary because both external and internal interests should be considered in the enactment of quality in higher education. This requires the alignment of external and internal mechanisms and protocols focusing on their practical value. Probably, this is why the international accounts show two principal forms of quality assurance in higher education, namely: external and internal quality assurance (Lewis, 2009; Martin \& Stella, 2007; Perellon, 2007; Okebukola, 2006). Both forms of quality assurance are considered necessary to effectively guarantee and enact quality in higher education (Poole, 20IO; Finnish Higher Education Evaluation Council, 2008) because of the need for a model that entails reciprocal roles and safeguards. This refocuses stakeholders' attention on the complementary roles of external and internal quality assurance, instead of potential differences that present tensions in implementation.

\section{The Relationship Between External and Internal Quality Assurance in \\ Higher Education}

Before the emergence of formalised external quality assurance in higher education through the establishment of quality assurance agencies, higher education institutions, especially universities, had no external accreditation for their programmes and had their own internal quality procedures, even though patchy and less formalised (Weusthof, I995). This gave higher education institutions the exclusive right to determine what constituted quality, and they developed their own mechanisms to maintain and improve the quality of higher education. This exclusive right was altered with the emergence of formalised external quality assurance structures at national and sub-national levels.

Formalised external quality assurance is meant to ensure that higher education institutions respond to the increasing demands and expectations of external stakeholders of higher education (Vlk, 2006). It is meant to guarantee standards of higher education by providing frameworks within which higher education institutions should function (Sanyal \& Martin, 2007). External quality assurance is always the responsibility of organisations external to the higher educational institutions (Skolnik, 2010). These external quality assurance agencies could be governmental or autonomous professional bodies. However, governmental bodies may have representation from professional bodies and vice versa (Billing, 2004). The rationale for external quality assurance is to safeguard the interests of external stakeholders and provide legitimacy for higher education institutions (Finnish Higher Education Evaluation Council, 2008; Santiago et al., 2008).

However, concerns have been raised about the accountability focus of external quality assurance agencies, whether sub-national, national or international bodies. According to a study conducted by Cheng (2009) in the United Kingdom, academic staff regarded external quality assurance as not making much impact on the quality of teaching. Ansah (20I0) presents an argument that the external quality assurance body in Ghana only checks basic inputs, which does not promote continued improvement in quality teaching and learning. Nonetheless, some authors (Santiago et al., 2008; Hopper, 2007; Higher Education Council of Australia, 1992) have argued that external quality assurance is in the interest of higher education institutions because it ensures their legitimacy in the eyes of the public and also enhances autonomy.

A formalised external quality assurance puts pressure on higher education institutions to have more formal internal quality assurance structures in exchange for increased autonomy, because it has become apparent that a well-established external quality assurance without a strong internal quality assurance would not lead to real improvement in quality (European Association for Quality Assurance, 20Io; Weusthof, I995). Kettunen (20I0, p. I) reports that the "European Ministers responsible for higher education agreed at a Bologna Process meeting that the primary responsibility of quality assurance lies with the higher education institutions". This reinforces the argument that a formalised internal quality assurance structure within higher education institutions is essential for effective enactment of quality in higher education. A formalised internal quality assurance has, therefore, become a higher 
education policy domain for most higher education systems (Finnish Higher Education Evaluation Council, 2008; Santiago et al., 2008). For example, in Ghana, it is mandatory for every higher education institution to establish an internal quality assurance directorate.

\section{Addressing the Nuances of the Tension from a Pragmatist Perspective}

The conceptualisations discussed so far affirm the legitimacy and urgency of both external and internal quality assurance in contemporary higher education in almost every higher education settings, but implementation still presents tensions in some higher education settings, due to the regulatory nature of external quality assurance. This is probably so because the nuanced relationships between the two principal forms of quality assurance in higher education are not clearly delineated, to explain their reciprocal roles and influences in enacting quality.

From a pragmatist standpoint, this situation leads to asking several questions whose answers lead to reduced tensions. Would internal stakeholders of higher education institutions perceive external quality assurance as only for accountability and not improvement, if they had been part of a negotiated settlement to approve the use of its mechanisms? On the other hand, are the internal stakeholders, especially academics, considering quality assurance only from an internal perspective of higher education? Do the external and internal stakeholders acknowledge that there are multiple realities of quality that require negotiations and settlements in the implementation of quality assur ance in higher education? Do both groups of stakeholders acknowledge that implementing quality assurance to improve higher education outcomes is a shared responsibility between external and internal quality assurance? Do the stakeholders (external and internal) admit that perspectives of quality change as a result of changing trends in higher education? Do these stakeholder groups recognise the context-specific need of quality assurance mechanisms in higher education?

These questions represent key pragmatist attributes that are useful to explain the nuances of the reciprocal roles and influences of external and internal quality assurance. They enable stakeholders to appreciate the complementary roles of external and internal quality assurance mechanisms, to avoid tagging one as only focused on accountability and the other only focused on improvement, and to consider both as nested concepts.

From a pragmatist standpoint, the relationship between external and internal quality assurance within the context of enacting quality in higher education can be represented with a nested Venn diagram, to better explain the relationships among quality and external and internal quality assurance, together with the reciprocities of roles and influences. This is presented in Figure I below.

Figure 1: Relationships between Quality, External and Internal Quality Assurance

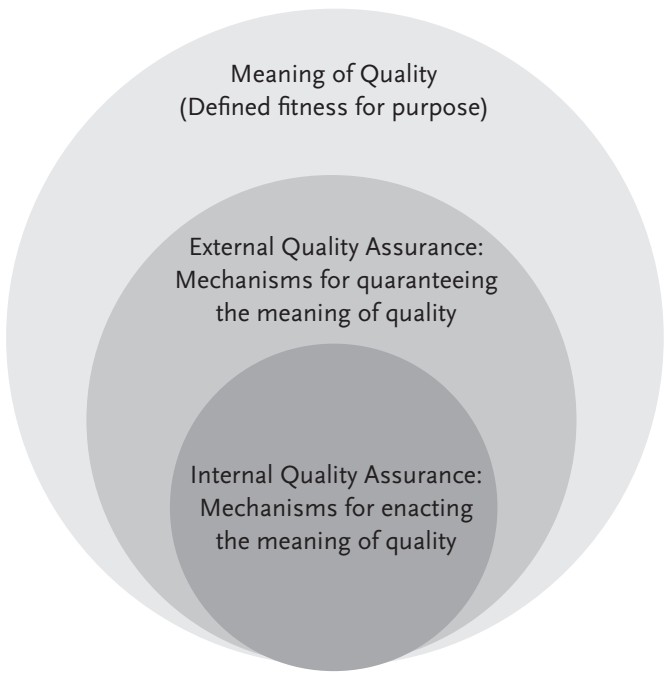

From a pragmatist view, quality should not be an abstract notion but a verifiable concept that can be practically enacted and measured. This starts with defining fitness for purpose in practical terms in a particular higher education setting. For instance, the meaning of fitness for purpose may focus on: training qualified human resources for the labour market; training students for research career; managing teaching provision efficiently; and producing graduates with the right skills and knowledge to contribute to development (Mishra, 2007; Barnett, I992). The fitness for purpose definition results from the alignment of both external and internal stakeholders' perspectives.

The fitness for purpose meaning is then safeguarded with mechanisms external to the higher education institutions, thereby producing external quality assurance to represent external stakeholders' expectations. This means that external quality assurance fits within the circle containing the meaning of quality for higher education institutions, which implies that higher education institutions must define their quality within the established fitness for purpose, which is subject to change based on changing trends in higher education. This helps to redirect the use of resources available to higher education institutions to focus on societal priorities. Any change to the priorities must be done through 
negotiation and settlement among stakeholders by providing logical proof of practical impact on society.

In order to ensure effective enactment of the meaning of quality, higher education institutions must also establish internal mechanisms to fit into the circle containing the meaning of quality for the various internal actors, thereby producing internal quality assurance. This also means that all internal actors within the higher education institutions must also focus on institutional priorities, and changes are made after consultations and settlements.

Figure I represents a pragmatist conceptualisation of quality, external, and internal quality assurance in higher education. It shows that quality produces external quality assurance and external quality assurance produces internal quality assurance which presupposes that external quality assurance is a subset of the concept of quality, whilst internal quality assurance is a subset of external quality assurance. The argument raised from Figure I is that the construct of quality determines the construct of external quality assurance, and the construct of external quality assurance determines the construct of internal quality assurance. It also means that external quality assurance and internal quality assurance are meant respectively to guarantee the meaning of quality and to enact it. The implication is that in the absence of a settled meaning of quality, external quality assurance and internal quality assurance have no practical relevance, because their only function is to guarantee and enact the meaning of quality.

From a pragmatist viewpoint, quality in higher education is best defined as fitness for purposes, which is the result of a negotiated settlement among key stakeholders including the funders, users of the products/programmes, users of outputs, and employees of the institutions (Srikanthan \& Dalrymple, 2003). The fitness for purpose construct is intended to be operationalised to suit a particular higher education setting. Whilst a particular higher education setting may focus on producing graduates for the labour market, another may focus on expanding the frontiers of knowledge. For example, fitness for purposes in the Ghanaian polytechnic education setting is operationalised as graduate employability competencies (Ansah, 20I3). Graduate employability competencies is considered fitness for purpose in Ghanaian polytechnics because it is believed to result from a settlement among the different stakeholders (external and internal) of polytechnic education (Ansah, 20I3).

Figure I shows that in order to guarantee the enactment of the fitness for purpose meaning of quality, quality assurance is required. This suggests that quality assurance must follow the same fitness for purposes concept. The mechanisms and the principles representing external quality assurance and internal quality assurance should be based on a settlement among the different stakeholders of the particular higher education setting where they are meant to be implemented. From a pragmatist standpoint, they are not mutually exclusive but complementary (Tuning, 2012; Commonwealth of Australia, 2009). Whereas internal quality assurance is needed to enact the meaning of quality (Poole, 2010; Doherty, 2008), external quality assurance is required to guarantee the enactment of quality (Santiago et al., 2008; Hopper, 2007). For example, in Ghana, external quality assurance agencies such as the National Council for Tertiary Education (NCTE), the National Accreditation Board (NAB), and the National Board for Professional and Technician Examination (NABPTEX) are responsible for guaranteeing graduate employability competencies in polytechnic education. The polytechnics are responsible for making sure that the competencies are delivered (National Council for Tertiary Education, 20II; Government of Ghana, I994). Figure I conceptualises the relationships between quality, external quality assurance, and internal quality assurance in terms of mutual effects and reciprocal necessity. The nested nature of the figure indicates that the three concepts are integrated and that there are reciprocities of roles and influences among them. For instance, quality needs external quality assurance for guarantee and internal quality assurance for enactment. External quality assurance and internal quality assurance on the other hand are also based on the meaning of quality in higher education (Cheng \& Tam, I997).

The use of circles to represent these concepts also has a pragmatist orientation. From a pragmatist perspective, the meaning of quality in higher education not only has multiple perspectives (Sebastianelli \& Tamimi, 2002; Srikanthan \& Dalrymple, 2003), but also shifting emphases (Badley, I993; Vroeijenstijn, I995). The circles are intended as indicative place holders for multiple constructs, and mechanisms for guarantee and enactment. This implies that external quality assurance and internal quality assurance have to move along with the changing meaning of quality as a result of changing trends in higher education. Figure I is a clear indication that activities of external quality assurance affect internal quality assurance, and the opposite is true as well. The implication is that constant negotiations and settlements are necessary for effective implementation of quality assurance in higher education.

\section{Conclusion}

The increasing attention that quality assurance is receiving in contemporary higher education is predicated on the perceived impact it is 
making on stakeholders' expectations of higher education outcomes. In order to guarantee and enact stakeholders' expectations of quality, external and internal quality assurance are, from a pragmatist perspective, considered complementary concepts, which require negotiation and settlement to address any tensions that affect effective implementation in higher education. The present focus on the complementary roles of external and internal quality assurance in many higher education jurisdictions is based on a pragmatist orientation, although not boldly acknowledged in the quality assurance literature on higher education. However, it is apparent that the emphasis on the reciprocal roles of external and internal quality assurance in higher education demands an explicit acknowledgement of the use of pragmatism, to address any existing tension in implementation jurisdictions where the concepts are treated as separate entities. Pragmatism focuses on the continuous alignment of different stakeholder perspectives through continuous negotiations and settlements. A pragmatist view considers external and internal quality assurance as two sides of the same coin, and such a view should be made explicit by theorists and practitioners of quality assurance in higher education.

\section{References}

Ansah, Francis. (20I0). Designing self-evaluation instruments for academic programmes: Lessons and challenges. Evaluation and Research in Education, 23(2), 77-90.

Bacon, Michael. (2012). Pragmatism: An introduction. Cambridge: Polity Press.

Badley, Graham. (I993). The Quality Debate in Higher Education. Professional Development in Education, 19(3), 23-28.

Barnett, Ronald. (I992). Improving higher education: Total quality care. Buckingham: Open University Press.

Bernhard, Andrea. (2012). Quality assurance in an international higher education area. Dordrecht: Springer.

Biesta, Gert. (20I0). Pragmatism and the philosophical foundations of mixed methods research. In A. Tashakori \& C. TEddlie (Eds.) SAGE handbook of mixed methods in social and behavioural research (2nd ed., pp. 95-II7). Thousand Oaks, CA: Sage.

Bigalke, Terance W. (2009). Increasing privatization of U.S. higher education: Forerunner or deviant case? In T. W. Bigalke \& D. E. Neubauer (Eds.), Quality and public good (pp. 49-62). New York: Palgrave Macmillan.

Bigalke, Terance W., \& Neubauer, Deane E. (2009). Quality and public good: An inseparable link. In T. W. Bigalke \& D. E. Neubauer
(Eds.), Quality and the public good (pp. I-I4). New York: Palgrave Macmillan.

Billing, David. (2004). International comparisons and trends in external quality assurance of higher education: Commonality or diversity? Higher Education, 47, II3-I37.

Blackmur, Douglas. (2007). The public regulation of higher education qualities: Rationale, processes, and outcomes In D. F. Westerheijden, B. Stensaker \& M. J. Rosa (Eds.), Quality assurance in higher education: Trends in regulation, translation and transformation (pp. I5-46). Dordrecht, Netherlands: Springer.

Cheng, Ming. (2009, 3Ist March). Academics' Professionalism and Quality Mechanisms: Challenges and Tensions. Paper presented at the INQAAHE Conference, Abu Dhabi.

Cheng, Yin Cheong, \& Tam, Wai Ming. (I997). Multi-models of quality in education. Quality Assurance in Education, 5(I), 22-3I.

Commonwealth of Australia. (2009). Transforming Australia's Higher Education System. Canberra: Commonwealth of Australia.

Dill, David D. (2007). Will market competition assure academic quality? An analysis of the UK and US experience. In D. F. Westerheijden, B. Stensaker \& M. J. Rosa (Eds.), Quality assurance in higher education: Trend in regulation, translation and transformation. (pp. 47-72). Dordrecht, Netherlands: Springer.

Doherty, G. (2008). On quality in education. Quality Assurance in Education, 16(3), 255-265.

Ewell, Peter. (2007). The 'quality game': External review and institutional reaction over three decades in the United States. In D. F Westerheijden, B. Stensaker \& M. J. Rosa (Eds.), Quality assurance in higher education: Trends in regulation, translation and transformation (Vol. 20, pp. II9-I53). Dordrecht, Netherlands: Springer.

Finnish Higher Education Evaluation Council. (2008). Audits of Quality Assurance Systems of Finnish Higher Education Institutions: Audit Manual for 2008-20II. Retrieved I4 May, 20I3, from http:// www.kka.fi/files/ı47/KKA_ıoo7.pdf

Frazer, Malcolm. (I994). Quality in higher education: An international perspective. In D. Green (Ed.), What is quality in higher education. London: Sage.

Government of Ghana. (I994). NABPTEX law, ACT 492. Accra: Government of Ghana.

Green, Diana. (I994). What is quality in higher education? Concepts, policy and practice. In D. Green (Ed.), What is quality in higher education (pp. 3-20). London: Sage.

Greene, Jennifer C., \& Hall, Jori N. (20I0). Dialectics and pragmatism: 
Being of consequence. In A. Tashakori \& C. Teddlie (Eds.), SAGE handbook of mixed methods in social and behavioural research (2nd ed., pp. II9-I4I). Thousand Oaks, CA: Sage.

Harvey, Lee, \& Green, Diana. (1993). Defining Quality. Assessment \& Evaluation in Higher Education, 18(I), 9-34.

Harvey, Lee, \& Knight, Peter T. (I996). Transforming higher education. London: Open University Press.

Harvey, Lee, \& Newton, Jethro. (2007). Transforming quality evaluation: Moving on. In D. F. Westerheijden, B. Stensaker \& M. J. Rosa (Eds.), Quality assurance in higher education: Trend in regulation, translation and transformation (pp. 225-246). Dordrecht, Netherlands: Springer.

Harvey, Lee, \& Williams, James. (2010). Fifteen years of quality in higher education. Quality in Higher Education, 16(2), 8I -II3.

Higher Education Council of Australia. (I992). Achieving Quality. Canberra: National Board for Employment, Education and Training.

Hopper, Richard R. (2007). Quality assurance and the World Bank: The challenge of context and capacity. In Y. C. Lopez, C. Escrigas, F. Lopez-segrera, B. C. Sanyal \& J. Tres (Eds.), Higher education in the world of 2007, accreditation for quality assurance: What is at stake? (pp. I68-I7I). New York: Palgrave Macmillan.

Kettunen, Juha. (2010). Cross-evaluation of degree programmes in higher education. Quality Assurance in Education, 18(I), 34-46.

Lewis, Richard. (2009). Quality Assurance in Higher Education: Its Global Future. In OECD (Ed.), Higher Education to 2030: Globalisation (Vol. 2, pp. 323-355). Paris: OECD.

Lokhoff, Jenneke, Wegewijs, Bas, Durkin, Katja, Wagenaar, Robert, González, Julia, Isaacs, Ann Katherine, . . . Gobbi, Mary (Eds.). (2010). A Tuning Guide to Formulating Degree Programme Profiles Including Programme Competences and Programme Learning Outcomes. Bilbao, Groningen and The Hague: Publicaciones de la Universidad de Deusto.

Martin, Michaela, \& Stella, Anthony. (2007). External quality assurance in higher education: Making choices. Paris: UNESCO.

Milliken, John, \& Colohan, Gerry. (2004). Quality or Control? Management in Higher Education. Journal of Higher Education Policy and Management, 26(3), 38I-39I.

Mishra, Sanjaya. (2007). Quality assurance in higher education: An introduction (Revised ed.). Bangalore, India: National Assessment and Accreditation Council (NAAC).

National Council for Tertiary Education. (20II). 2009 Annual Report. Accra: National Council for Tertiary Education.
OECD. (2006). Higher education: Quality, equity and efficiency. Education Policy Analysis, 9-66.

Okebukola, P.A.O. (2006). Perception of quality assurance practices in higher education in Africa. NUC Monograph Series, 3(I), I2-I5.

Oyewole, Olusola. (20I2). Developing quality assurance systems in African universities: AAU initiatives. In G. B. Alabi \& J. C. Mba (Eds.), The quality assurance situation and capacity building needs of higher education in Africa (pp. I-I6). Accra: Association of African Universities.

Perellon, Juan F. (2007). Analysing quality assurance in higher education: Proposals fora conceptual framework and methodological implications. In D. F. Westerheijden, B. Stensaker \& M. J. Rosa (Eds.), Quality assurance in higher education: Trends in regulation, translation and transformation (Vol. 20, pp. 155-I78). Dordrecht, Netherlands: Springer.

Poole, Brian. (2010). Quality, semantics and the two cultures. Quality Assurance in Education, 18(I), 6-18.

Santiago, Paulo, Tremblay, Karine, Basri, Ester, \& Arnal, Elena. (2008). Tertiary education for the knowledge society: Governance, funding and quality (Vol. I). Paris: OECD.

Sanyal, Bikas C., \& Martin, Michaela. (2007). Quality assurance and the role of accreditation: An overview. In Y. C. Lopez, C. Escrigas, F. Lopez-segrera, B. C. Sanyal \& J. Tres (Eds.), Higher education in the world of 2007, accreditation for quality assurance: What is at stake? (pp. 3-I7). New York: Palgrave Macmillan.

Schwartz, Robert. (2012). Rethinking Pragmatism: From William James to contemporary philosophy. West Sussex, UK: Wiley-Blackwell.

Schwarz, Stefanie, \& Westerheijden, Don F. (2007). Accreditation in the framework of evaluation activities: A comparative study in the European Higher Education Area. In S. Schwarz \& D. F. Westerheijden (Eds.), Accreditation and evaluation in the European Higher Education Area (Vol. 5, pp. I-42). Dordrecht, The Netherlands: Springer.

Sebastianelli, Rose, \& Tamimi, Nabil. (2002). How product quality dimensions relate to defining quality. International Journal of Quality Q Reliability Management, 19(4), 442-453.

Singh, Mala. (20I0). Quality Assurance in Higher Education: which pasts to build on, what futures to contemplate? Quality in Higher Education, 16(2), I89-194.

Skolnik, Michael L. (20I0). Quality assurance in higher education as a political process. Higher Education Management and Policy, 22(I), I-20.

Srikanthan, G., \& Dalrymple, J. F. (2003). Developing alternative per- 
spectives for quality in higher education. International Journal of Educational Management, 17(3), I26-136.

Stensaker, B. (2007). Quality as fashion: Exploring the translation of management idea into higher education. In D. F. Westerheijden, B. Stensaker \& M. J. Rosa (Eds.), Quality assurance in higher education: Trend in regulation, translation and transformation (Vol. 20, pp. 99-II8). Dordrecht, Netherlands: Springer.

Tuning. (20I2). Tuning Educational Structures in Europe Project. Retrieved 30 November, 2012, from http://www.unideusto.org/ tuningeu/home.html

Tuning Educational Structures in Europe Project. (20I2). Tuning Methodology. Retrieved IIth October, 20I2, from http://tuning. unideusto.org/tuningeu/

Vidovich, Lesley. (2002). Quality assurance in Australian higher education: Globalisation and 'steering at a distance'. Higher Education, 43, 39I-408.

Vlk, A. (2006). Higher education and GATS: Regulatory consequences and stakeholders' response Enschede: CHEPS, University of Twente.

Vroeijenstijn, A.I. (I995). Improvement and accountability: Navigating between Scylla and Charybdis - Guide for external quality assurance in higher education. London: Jessica Kingsley.

Westerheijden, Don F., Stensaker, Bjorn, \& Rosa, Mria Joao. (2007). Transformation and continuity: Another book on quality? In D. F. Westerheijden, B. Stensaker \& M. J. Rosa (Eds.), Quality assurance in higher education: Trend in regulation, translation and transformation (pp. I-II). Dordrecht, Netherlands: Springer. 